\title{
CONCEPTUAL PRINCIPLES OF LEARNING ORGANIZATION
}

\begin{abstract}
The main purpose of this study is to present conceptual principles of the learning organisation as a modern form of functioning of contemporary organisations and enterprises and the awareness of the dominant role of intangible resources. The most important factor that protects organizations from solidifying is knowledge. In an organization, knowledge is produced by people and these people learn. However, learning alone is not sufficient for the success of the organization. For a lasting and sustainable process, organizational learning is required. Knowledge, on the other hand, is inextricably linked to human capital, which is now the most valuable resource of the new forms of organisation.
\end{abstract}

Keywords: management, learning organisation, modern enterprise.

\section{INTRODUCTION}

The focusing of modern economics on the formation, development and implementation of basic learning organizations conceptual provisions points is due to the latest processes in the business environment, in particular: the formation of a knowledge-based economy; intensification of business entities restructuring processes; effective use of intellectual potential and accumulation of intellectual capital in enterprises; the conceptual foundations of strategic planning revision, etc.

The analysis of the most important features of modern enterprise models shows that they optimise their activities based on the maximum use of the concept of a learning organisation. This is because thanks to new applications of human competences and knowledge, the modern enterprise provides itself with a competitive advantage. And for this it is necessary to develop a conscious organisation subordinated to knowledge. It should be noted that the author does not distinguish between the concepts of "organisation" and "enterprise". It is assumed that both notions can be used interchangeably to describe entities conducting economic activity. A similar opinion prevails among the majority of authors of scientific and research works.

\section{LITERATURE OVERVIEW}

The concept of the learning organisation emerged in the 1980s and eventually developed in the 1990s (Seebacher, 2002). The increased interest in this issue was closely related to the coming era of the knowledge and information society (Stańczyk-Hugiet, 2005). Today,

\footnotetext{
${ }^{1}$ Marcin Kłak, PhD, Eng., Rzeszow University of Technology (Faculty of Management), Al. Powstańców Warszawy 12, 35-959 Rzeszow, Poland; e-mail: mk@ prz.edu.pl. ORCID: 0000-0003-3673-1924.
} 
the phrase "learning organisation" is one of the most fashionable concepts, and although many organisations identify with this way of functioning, not all managers yet know what it means or misunderstand it. The learning organisation is now seen as a tool of modern management. The success of a modern organisation depends on the ability to recognise and search for new ways of doing things (Batorski, 1998; Korn i in., 2021). However, this only takes place with the involvement of the organisation as a whole, especially in networked (Skrzypek, 2020) or dispersed organisations (Zaskórski, Zaskórski, Woźniak, 2021).

Consciousness of an organisation (company) is an intangible way of existence of a market entity (legal entity). It is a product of experiencing the market position of the company by the people who make up this entity (Jarosiewicz, 2021). Under these circumstances, the success of the concept of a learning organisation becomes understandable.

The very concept of a learning organisation is defined as an organisation in which learning is a continuous process (Finger, Brand, 1999; Örtenblad, 2018). This process is, as it were, a condition for the life of the organisation (Fig. 1).

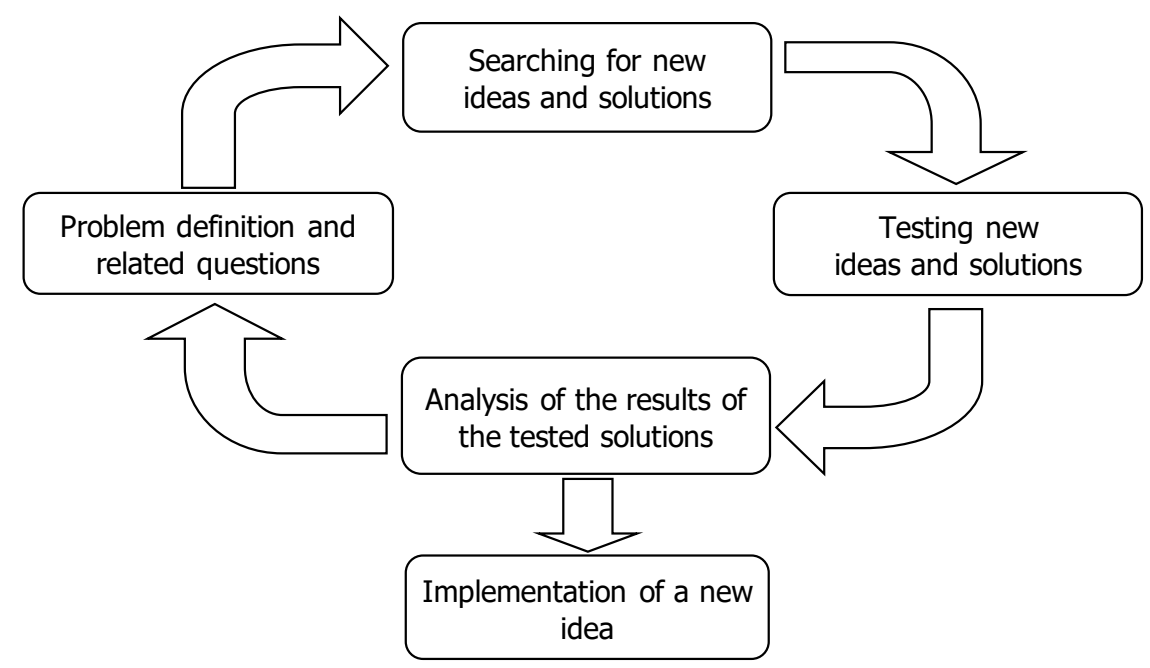

Figure 1. The organisation's learning process

Source: Authors' own elaboration based on (Senge, 1998).

A learning enterprise is one that requires all its employees to learn in order to transform both itself and the environment in which it operates (Bieniok, Głód, 2003). This is because it is about the permanent acquisition of knowledge and skills in planning, organising, motivating and controlling, preparing people to perform the role of company management, and developing individual managerial skills (Bańka, 2002). In such organisations, acquiring new or improving already existing qualifications will determine the professional and social advancement of a large group of employees, the prestige of a new profession, and as a result, progress in various areas of the economy (Bitkowska, Sobolewska, 2020). 


\section{RESEARCH AND DISCUSSION}

\subsection{Conceptual principles for organisational learning}

It is becoming commonplace to say that the organisations that can consciously compete in the future will be those that discover how to harness human engagement and learning opportunities at all levels, and those whose rate of learning is faster than the rate at which their environment changes.

The challenges posed to the employee by the modern enterprise are the constant need to learn, to acquire knowledge and to change (Fig. 2). The direction of these changes is determined by the assumption that the condition of individual development is change and the constant process of learning through acquiring new knowledge, experiencing new phenomena, learning by doing, by experiencing. Peter M. Senge claims that "True learning goes to the very bottom of what it means to be human. Through learning we transform ourselves, develop our creative capacities, and become part of the creative processes of life" (Senge, 1992).

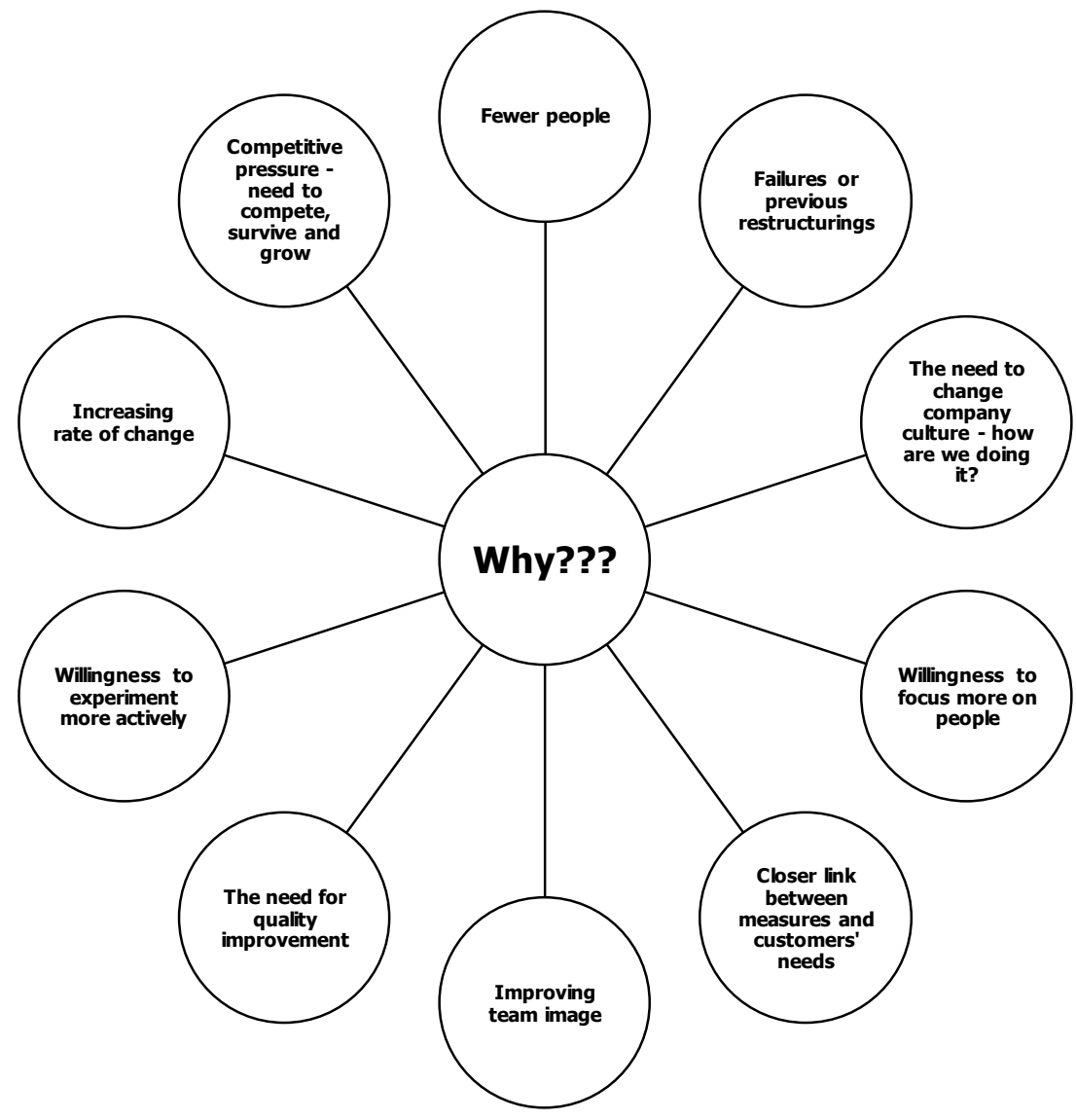

Figure 2. The main conceptual principles of corporate learning

Source: Authors' own elaboration based on (Pedler, Aspinwall, 1999). 


\subsection{Continuous improvement as the basis for a learning organisation}

A learning organisation is not possible without a shared vision that unites all members of the organisation (Jagodzinski, 2018). It must be a vision shared and approved by all employees of the company, not the visions of individuals, owners or managers, imposed on other colleagues (Meen, Keough, 1992; Jackson, 2021). Such collaborative learning is primarily based on: creative rethinking of complex problems so as to achieve synergy; innovative yet coordinated action; and mutual support by members of different teams. Thus, although individual knowledge and skills are used, it is a team discipline that primarily requires dialogue, discussion, communication and trainings (Bańka, 2002).

The strategy of a learning enterprise is based on the ability to own development, to develop new and useful solutions, to create a new reality (Soniewicki, 2019), closing the emerging knowledge gaps (Fig. 3). This is fostered by purposeful motivating, inspiring activities, identifying opportunities for development, experimentation and systematic training (Baruk, 2006).

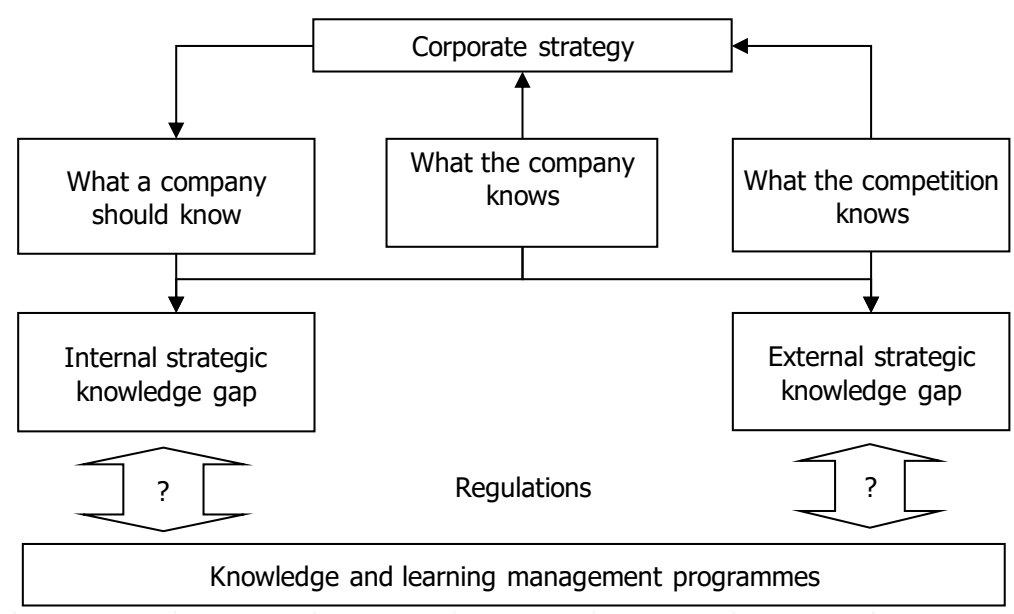

Figure 3. Corporate strategy based on knowledge management and learning processes

Source: Authors' own elaboration based on (Clarke, 2001).

All decisions made in a learning organisation are based on existing knowledge, and each new experience is a basis for extending this knowledge. A learning organisation is based on the intellectual and intuitive potential of all its employees, who strive for its continuous development in order to achieve their own goals ${ }^{2}$. One reacts with equal commitment to the signals sent by the market, in terms of suppliers, customers and competitors, one targets the needs of employees in order to increase their participation in the management of the enterprise (Illiashenko, 2020). Activities are supported that are aimed at continuously increasing the potential of its knowledge. It focuses the efforts of all its participants to

2 An excellent example of continuous improvement and organisational learning is the Procter \& Gamble company. The marketing strategy used for the 'Tide' brand, introduced in 1947, meant that as late as 1976 the product life cycle was still in the growth phase, with 55 product modifications introduced during this period. More: (Lambin, 2001). 
accumulate the most valuable capital, knowledge capital, in order to ensure its advantage over its competitors, manifested by the creation of mechanisms that allow it to effectively exploit changes in its environment (Nonaka, 1995; Bayraktar, 2019).

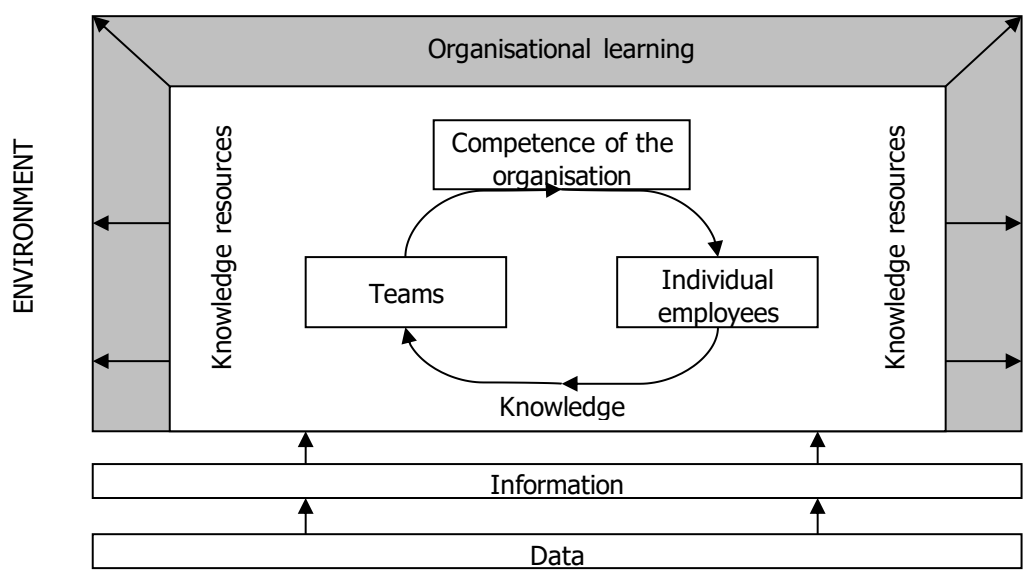

$\sum_{\substack{\text { 岁 } \\ \text { 点 }}}$

Figure 4. Structure of knowledge resources in a learning organisation

Source: Authors' own elaboration based on (Probst, Raub, Romhardt, 2002).

In order to achieve this goal, changes should be made in the organisation to enable the formation of working groups (teams) focused on solving immediate tasks, depending on the situation (Fig. 4). Ensuring the mobility of employees within the organisation, the possibility to immediately focus on taking advantage of changes in the environment, will be ensured by creating modern, flexible arrangements between individual cells, or rather people gathered around them. The knowledge acquired by the actors of these relationships, or rather the possibility of its immediate use in every part of the enterprise, enables the smooth functioning of the learning enterprise (Chmielewska-Muciek, 2018). In its fundamental dynamics, the organisation has the ability to achieve high rates of entrepreneurship and economic growth, as well as creating the capacity and skills to carry out reconnaissance, skilful adaptation to the environment, innovation and productivity in execution (Batorski, 1998; Alerasoul, Afeltra, Hakala, Minelli, Strozzi, 2021).

\subsection{Flexible structure of the learning organisation}

An important issue concerning learning organisations is the determination of the characteristics of its organisational structure. In the literature one can find views accepting the "anti-structurality" or "structurelessness" of the learning organisation (Hopej, 2000). However, one can see statements that a learning organisation without structural solutions could not establish its boundaries as relatively unchanging in time and stable. Such an organisation, in spite of its development potential, would constantly jeopardise its sustainability and identity and eventually liquidate itself. Thus neither structure nor learning can function separately. In learning organisations, only the integration of these two elements forms the basis for their existence (Handy, 1998). 
The organisational structure is an essential element of a learning organisation, but it cannot be a rigid structure with a high degree of centralisation, formalisation and extensive organisational hierarchy. Such a structure hinders learning by making it difficult to develop a common vision and a shared understanding of organisational problems and teamwork.

The lack of divisions, levels, barriers and the changing importance of strategic resources have forced the emergence of flexible structures, in which divisions are fluid and boundaries between levels and departments permeable, allowing information, resources, ideas and energy to flow freely. Every employee takes part in formulating the company's strategy, which makes it possible to draw on their knowledge and experience and increases employees' personal involvement in its implementation. The decentralised structure of the learning organisation is expressed in the delegation of authority and responsibility according to roles within the organisation (Steinmann and Schreyogg, 1998; Hanif, Anwar, Hamid, 2018).

A learning enterprise is an effective and friendly organisation, because in this enterprise the traditional forms of hierarchy are replaced by loosely linked groups of specialists, who come together on an ad hoc basis to carry out a task, as well as the participation of employees in the management of the enterprise becomes one of the characteristics (Hopej, 2000).

However, a learning organisation cannot do without some kind of hierarchy. In learning organisations we can speak of two levels of management - the central management level and the local level. In this structure, the managers of the local levels have very broad powers, taking total responsibility for the development and activities of their organisational units.

With a very high degree of local autonomy, central management should focus its attention on the essential issue, i.e. shaping the organisation's capacity to learn. In particular, its functions will consist of (Laudon, Starbuck, 2000):

- Managing the organisation's resources,

- Developing main ideas,

- Defining core values,

- Defining and developing the future vision and mission,

- Studying the organisation as a system,

- Designing learning processes.

However, few modern senior managers are able to perform these functions properly and this is one of the main reasons that truly learning organisations are still rare.

An interesting view is held by G. Morgan, who states that hierarchy is a necessary attribute of a learning organisation. It should learn and self-organise like a functioning brain, and this usually involves adapting some sort of hierarchically structured pattern, which is the form of adaptation that an organisation takes when faced with complexity. Hierarchy, however, is not imposed but rather "emerges" (Morgan, 1997).

In learning organisations, managers should take on the role of creating the conditions for others to act. They should allow subordinates to self-direct their own actions within a common set of norms and values that foster a shared identity and learning orientation. At the same time, they must encourage them to question whether these norms and values are an appropriate basis for guiding organisational behaviour. This is because it assumes that shared norms and values need to evolve with changing circumstances. 
Furthermore, the structure of the learning organisation must not limit the variety and range of activities to a great extent. It should be based on the principle of function redundancy, which states that "instead of adding spare parts to the system, additional parts are allocated to each of the functioning parts, so that each part can fulfil a range of functions rather than just performing one specialised activity" (Morgan, 1997). Its application in practice generally leads to autonomous work groups whose members have a variety of skills to enable job rotation, and each member has an excess of skills in the sense that they are not fully utilised in the work currently being done. Everyone needs to do something more, to show initiative, responsibility and to go beyond the familiar. The participants in a learning organisation should therefore have only their basic responsibilities defined and a broad field of action outlined on their own.

Therefore, it can be concluded that the structure of a learning organisation is characterised by high flexibility (Jettka, 2018). This is evidenced by a weakly marked hierarchy, broad powers of the executive level, little specialisation and formalisation of activities. These structural arrangements of learning organisations are flexible due to the not very clear dividing lines between superiors and subordinates, customers and suppliers, the organisation and the environment, and an efficient information system providing the requested information to the appropriate hierarchical levels - where it is needed (Zimniewicz, 2003).

\subsection{Main barriers and benefits of organisational learning}

The conscious implementation and realisation of the concept of organisational learning encounters many barriers and limitations. These constraints cause the organisation to learn the wrong things (Hatch, 2002).

The main barriers of organisational corporate learning can be divided into (Czapla, Malarski, 2005):

- Psychosocial - lack of trust, unwillingness to cooperate, lack of openness, communication problems,

- Cultural - lack of identification with the vision, mission and objectives of the company, lack of activities to support knowledge sharing, lack of a sense of community,

- Technical - lack of technical and IT infrastructure to transmit and collect data,

- Organisational - rigid and hierarchical organisational structure, bureaucratic forms of employee cooperation, lack of procedures and mechanisms for knowledge sharing.

Participation in organisational learning processes also has a number of positive benefits for both the employee and the enterprise. Table 1 shows the potential benefits for the employee - as an individual, and the enterprise - as an organisation.

An approach focused on releasing employees' creative abilities, consequently leads to improving the organisation's efficiency, and thus to achieving a competitive advantage on the market (Fig. 5). 
Table 1. The benefits of learning from the perspective of the employee and the company

\begin{tabular}{|c|c|}
\hline Pot & fits for the organisation \\
\hline $\begin{array}{l}\text { founded } \\
\text { a variety of } \\
\text { alisation } \\
\text { lge and } \\
\text { ng and } \\
\text { n beliefs with } \\
\text { embers } \\
\text { ganisation } \\
\text { and its } \\
\text { ncrease } \\
\text {, which is } \\
\text { elopment of } \\
\text { y based on } \\
\text { id skills } \\
\text { exchange of } \\
\text { reflections } \\
\text { dge base } \\
\text { te actions, } \\
\text { knowledge, } \\
\text { skills }\end{array}$ & $\begin{array}{l}\text { e and anticipatory behaviour } \\
\text { organisational climate based on teamwork } \\
\text { ment and building of a competitive advantage } \\
\text { distinctive competences } \\
\text { of knowledge transfer and accumulation } \\
\text { generic competencies } \\
\text { ment of learning systems and their control } \\
\text { gg objectives and implementing strategies } \\
\text { organisational knowledge resources for use in } \\
\text { unforeseen situations } \\
\text { ed learning processes provide assurance of } \\
\text { within formal boundaries } \\
\text { formal learning systems can be a source of } \\
\text { development of organisational knowledge assets } \\
\text { formance as a result of practical applications of } \\
\text { ge resources } \\
\text { orientation for continuous improvement and } \\
\text { motivation } \\
\text { organisational knowledge assets and managing } \\
\text { ge } \\
\text { while doing gives a resource of practical } \\
\text { nowledge } \\
\text { ment to learning, development of learning } \\
\text { mes, acquiring knowledge in predefined areas } \\
\text { es for organisational knowledge, often tacit, } \\
\text { in potentially be externalised and used by the } \\
\text { tion }\end{array}$ \\
\hline
\end{tabular}

Source: Adapted from (Stańczyk-Hugiet, 2005).

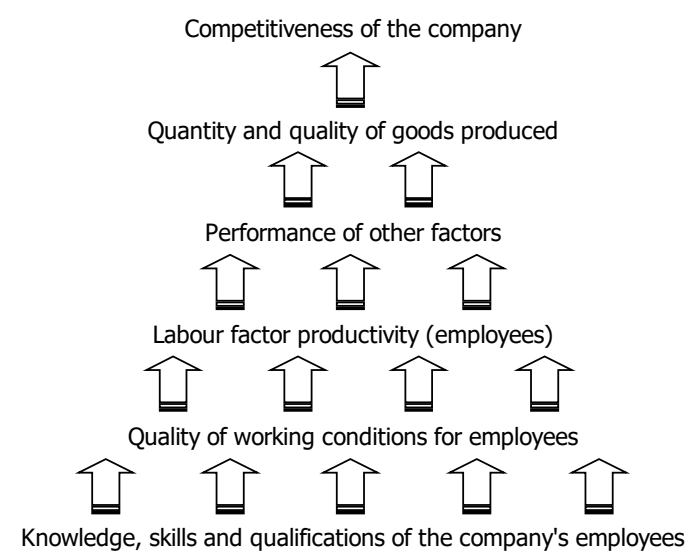

Figure 5. Impact of knowledge, skills and qualifications of employees on the competitiveness of the company

Source: Authors' own elaboration based on (Czerniachowicz, 2003). 
A learning enterprise is based on assumptions that emphasise the importance of human capital. Therefore, it releases the creative abilities of employees, increases their personal motivation, which leads to an improvement in the effectiveness of the company. This influences the realisation of goals convergent for all employees, which are: gaining a competitive advantage in the company's environment and increasing its competitiveness (Adamkiewicz, 2000).

\section{CONCLUSIONS AND RECOMMENDATION}

Knowledge is the basis for the existence and functioning of any conscious organisation. It seems, however, that it is in the learning organisation that knowledge takes on special significance. Without knowledge and its appropriate management, a learning organisation would not exist. It is the acquisition of knowledge and its subsequent use in practice for the benefit of the organisation and its employees that leads to continuous improvement, the development of skills to make them better and better and thus lead to the development of the organisation and its participants. This approach also requires conscious leadership (Krasnosielski, Nowak, 2021), as no development is possible without knowledge and its continuous improvement.

The process of conscious education is obviously inseparably connected with knowledge, its acquisition, transfer and accumulation, i.e. all that is included in the concept of "Knowledge Management" (Pedler, Aspinwall, 1999; Helbig, Hofhues, Egloffstein, Ifenthaler, 2021). As a learning organisation relies on the key talents of its employees, on their explicit and tacit knowledge, it becomes necessary to constantly supplement, update and create it in order to keep up with the constantly changing world, technologies, operating and business conditions (Fig. 6).

The ability to learn quickly is proving to be the only sustainable competitive advantage. It is no longer possible to set goals at the top of a hierarchy and tell others to follow. Instead, the winners of the future will be those organisations that discover how to harness their members' commitment and learning capabilities at all levels.

Modern companies can be effective and employee-friendly if they find a way to change their internal working relationships from antagonistic to partnership, integrating employee teams around the core problems and challenges that the company faces in a turbulent contemporary environment. And allowing employees to participate in the management process definitely contributes to the realisation of such intentions.

Conscious use of the potential inherent in employees, creation of conditions for sharing knowledge and improving qualifications by members of the organisation directly influences the effectiveness of management in companies and an increase in work productivity, which contributes to the development of enterprises and, on the market, an increase in their competitiveness.

Thanks to the fact that a learning organisation has up-to-date information and the latest knowledge, it is able to use these resources to gain a competitive advantage and ensure its survival. Such an organisation quickly adapts to the changing environment, is open to change and is ready to reject all templates for predictable action by the competition. 




Figure 6. The mechanism of learning organization knowledge creation and use Source: (Ostrovska, Sherstiuk, Tsikh, Demianyshyn, Danyliuk-Chernykh, 2021). 


\section{REFERENCES}

Adamkiewicz, H. G. (2000). Znaczenie zasobów ludzkich w przedsiębiorstwie o charakterze organizacji inteligentnej $w$ świetle konkurencyjności [in:] Instrumenty zarzadzania we współczesnym przedsiębiorstwie. Poznań: Zakład Graficzny AE w Poznaniu.

Alerasoul, S., Afeltra, G., Hakala, H., Minelli, E., Strozzi, F. (2021). Organisational learning, learning organisation, and learning orientation: An integrative review and framework. "Human Resource Management Review", 2021. DOI: 10.1016/j.hrmr.2021.100854.

Bańka, W. (2002). Wiedza w małej i średniej firmie. Płock: Novum.

Baruk, J. (2006). Zarządzanie wiedza i innowacjami. Toruń: Wydawnictwo Adam Marszałek.

Batorski, J. (1998). Organizacja uczaca się jako narzędzie nowoczesnego zarządzania. "Personel i Zarządzanie", nr 6 (51).

Bieniok, H., Głód, G. (2003). Organizacja uczaca się w świetle badań matych i średnich przedsiębiorstw województwa śląskiego [in:] Zimniewicz, K., red., Instrumenty zarządzania we współczesnym przedsiębiorstwie, Poznań: Wydawnictwo Akademii Ekonomicznej.

Bitkowska, A., Sobolewska, O. (2020). Zarzadzanie procesowe z wykorzystaniem wiedzy w polskich przedsiębiorstwach. "Przegląd Organizacji”, nr 1.

Chmielewska-Muciek, D. (2018). Knowledge Management Process in the Light of the Literature of the Subject. "Annales Universitatis Mariae Curie-Skłodowska", Sectio H. Oeconomia, Vol. 52, $\mathrm{nr} 1$.

Clarke, Th. (2001). The knowledge economy. "Education + Training”, No. 4/5.

Czapla, T., Malarski, M. (2005). Zarządzanie pozyskiwaniem i rozwojem wiedzy w organizacji [in:] Błaszczyk, W., red., Metody organizacji i zarzadzania. Kształtowanie relacji organizacyjnych. Warszawa: Polskie Wydawnictwo Naukowe.

Czerniachowicz, B. (2003). Organizacja uczaca się a organizacja inteligentna [in:] Kopycińska, D., red., Kapitat ludzki w gospodarce. Szczecin: Polskie Towarzystwo Ekonomiczne.

Finger, M., Brand, S. (1999). The Concept of the 'Learning Organization' Applied to the Transformation of the Public Sector [in:] Easterby-Smith, M., Araujo, L., Burgoyne, J., red., Organizational Learning and Learning Organization. Developments in Theory and Practice. London: Sage Publications.

Handy, Ch. (1998). Wiek przezwyciężonego rozumu, Warszawa: Business Press.

Hanif, M., Anwar, Z., Hamid, A. (2018). The Impact of Organic Structure on HR Practices with Mediation Role of Learning Organization. "International Journal of Management Excellence", 11(1). DOI: 10.17722/ijme.v11i1.997.

Hatch, M. J. (2002), Teoria organizacji. Warszawa: Polskie Wydawnictwo Naukowe.

Helbig, C., Hofhues, S., Egloffstein, M., Ifenthaler, D. (2021). Digital Transformation in Learning Organizations. "Springer International Publishing”, 2021. DOI: 10.1007/978-3030-55878-9_14.

Hopej, M. (2000). Struktura organizacji uczacej się [in:] Grudzewski, W. M., Hejduk, I. K., red., Przedsiębiorstwo przyszłości. Warszawa: Difin.

Illiashenko, S. (2020). Knowledge management at industrial enterprises in the context of forming their innovative development strategies [in:] Spałek, S., red., Systemy informacyjne $i$ zarzadzanie wiedza. Wybrane zagadnienia. Warszawa: Wydawnictwo CeDeWu.

Jackson, B. (2021). Peter Senge and the learning organization, "Routledge" 2021. DOI: $10.4324 / 9780203471999-11$. 
Jagodziński, A. (2018). Koncepcje zorientowane na wiedzę. „Zeszyty Naukowe Państwowej Wyższej Szkoły Zawodowej w Płocku, Nauki Ekonomiczne", t. 28.

Jarosiewicz, H. (2014). Świadomość organizacji. Klimat i kultura organizacji [access: 01.09.2021]. Access on the internet: http://kapitalkariery.pl/images/Swiadomosc_ organizacji_-_klimat_i_kultura_wersja_IV_.pdf.

Jettka, J. (2018). Bez hierarchii... Droga do świadomej organizacji. Kraków: Wydawnictwo Ridero.

Krasnosielski, D., Nowak, M. (2021). Świadome przywództwo. Poznań: Wydawnictwo FNCE.

Korn, R., Chandler, K., Marzec, C. (2021). Becoming a Learning Organization. "Curator", 64(2). DOI: 10.1111/cura.12419.

Lambin, J. (2001). Strategiczne zarzadzanie marketingowe. Warszawa: Polskie Wydawnictwo Naukowe.

Laudon, K., Starbuck, W. H. (2000). Organizational Informational Knowledge [in:] Zeleny, M., red., The IEBM Handbook of Information Technology in Business. London: Thomson Learning.

Meen, D. E., Keough, M. (1992). Creating the Learning Organization. An Interview with Peter M. Senge. "The McKinsey Quarterly", No. 1.

Morgan, G. (1997). Obrazy organizacji. Warszawa: Polskie Wydawnictwo Naukowe.

Nonaka, I., Takeuchi, H. (1995). The Knowlegde Creating Company. New York: Oxford Uniwersity Press.

Ostrovska H., Sherstiuk R., Tsikh H., Demianyshyn V. H., Danyliuk-Chernykh I. M. (2021). Conceptual principles of learning organization building. "Naukovyi Visnyk Natsionalnoho Hirnychoho Universytetu", 2021(3). DOI: 10.33271/nvngu/2021-3/167.

Örtenblad, A. (2018). What does "learning organization" mean? "The Learning Organization", Vol. 25, No. 3. DOI: 10.1108/TLO-02-2018-0016.

Pedler, M. J., Aspinwall, K. (1999), Przedsiębiorstwo uczace się, Petit, Warszawa.

Probst, G., Raub, S., Romhardt, K. (2002). Zarządzanie wiedza w organizacji. Kraków: Oficyna Ekonomicza.

Seebacher, U. S. (2002). Cyber Commerce Reframing. The End of Business Process Reengineering?. Berlin-Heidelberg: Spring-Verlag.

Senge, P. M. (1992). Creating the learning organization. "The McKinsey Quarterly", No. 1.

— (1998). Piata dyscyplina. Teoria i praktyka organizacji uczacej się. Warszawa Dom Wydawniczy ABC.

Skrzypek, A. (2020). Zarządzanie wiedza w społeczeństwie sieciowym. Siedlce: Uniwersytet Przyrodniczo-Humanistyczny w Siedlcach.

Soniewicki, M. (2019). Zarządzanie wiedza w procesie offshoringu-studia przypadku centrów ustug biznesowych. "Przegląd Organizacji", nr 2(949).

Stańczyk-Hugiet, E. (2005). Organizacja ucząca się [in:] Krupski, R., red., Zarządzanie przedsiębiorstwem $w$ turbulentnym otoczeniu. Warszawa: Polskie Wydawnictwo Ekonomiczne.

Steinmann, H., Schreyogg, G. (1998). Zarządzanie. Wrocław: Oficyna Wydawnicza Politechniki Wrocławskiej. 
Zaskórski, P., Zaskórski, W., Woźniak, J. (2021). Świadomość sytuacyjna a bezpieczeństwo $i$ informacyjna ciagłość działania $w$ organizacjach rozproszonych. Warszawa: Wydawnictwo CeDeWu.

Zimniewicz, K. (2003). Współczesne koncepcje i metody zarządzania. Warszawa: Polskie Wydawnictwo Ekonomiczne.

DOI: $10.7862 / \mathrm{rz} .2021 . \mathrm{mmr} .24$

The text was submitted to the editorial office: September 2021.

The text was accepted for publication: December 2021. 
